\title{
Short communication: Bovine a-casein is a ferritin-binding protein and inhibitory factor of milk ferritin immunoassay
}

\author{
G. Sugawara, ${ }^{*}$ R. Inoue, ${ }^{*}$ K. Watanabe, ${ }^{*}$ H. Ohtsuka, $†$ and K. Orino ${ }^{* 1}$ \\ *Veterinary Biochemistry Laboratory, and \\ †Large Animal Internal Medicine Laboratory, School of Veterinary Medicine, Kitasato University, Aomori 034-8628, Japan
}

\begin{abstract}
Commercial bovine milk $\alpha$-casein, but not $\beta$ - and $\kappa$-caseins, bound to bovine spleen ferritin, as determined by an immunoassay for ferritin. In contrast, $\alpha$-casein did not bind to apoferritin. The binding of $\alpha$-casein to bovine spleen ferritin was strongly inhibited by increasing ionic strength by the addition of $0.5 \mathrm{M}\left(\mathrm{NH}_{4}\right)_{2} \mathrm{SO}_{4}$. The addition of $\alpha$-casein to a known amount of bovine spleen ferritin resulted in significantly lower recovery (78-80\%) of added ferritin, although $\beta$ - and $\kappa$-caseins showed little inhibitory effect in the ferritin immunoassay. These results indicate that bovine $\alpha$-casein is a specific ferritin-binding protein that may inhibit milk ferritin immunoassay.
\end{abstract}

Key words: $\alpha$-casein, ferritin, immunoassay, milk

Ferritin, an iron-binding protein, is a ubiquitous protein found in all living organisms (Theil, 1987). Intracellular ferritin has the dual function of storing iron in a biologically available form and segregating iron species for the prevention of oxidative stress by iron-catalyzed production of reactive oxygen species (Harrison and Arosio, 1996; Orino and Watanabe, 2008). In humans, ferritin is present in relatively low concentrations $(<1$ $\mu \mathrm{g} / \mathrm{mL}$ ) in extracellular fluids such as milk (Arosio et al., 1986) and synovial fluid (Ota and Katsuki, 1998), as well as in blood (Addison et al., 1972; Walters et al., 1973). Serum ferritin levels positively correlate with body iron stores (Addison et al., 1972; Walters et al., 1973). In addition, ferritin concentrations in serum (Lorier et al., 1985), milk (Orino et al., 2006b), and synovial fluid (Ota and Katsuki, 1998) increase during inflammatory disease.

In serum ferritin immunoassay, the following ferritinbinding proteins (FBP), which probably circulate in the form of complexes with ferritin, have been identified: H-kininogen (Torti and Torti, 1998), $\alpha-2-$

Received December 4, 2008.

Accepted May 1, 2009.

${ }^{1}$ Corresponding author: orino@vmas.kitasato-u.ac.jp macroglobulin (Santambrogio and Massover, 1989; Massover, 1994), anti-ferritin autoantibodies (Orino et al., 2004, 2006a), fibrinogen (Orino et al., 1993b), and apolipoprotein B (ApoB; Rashid et al., 2002; Seki et al., 2008). Inhibitory effects of horse and bovine sera on immunoassay for ferritin were observed, suggesting that FBP conceal the epitope for anti-ferritin antibodies used in immunoassays (Orino et al., 1993a,b, 2004). Additionally, the inhibitory effect of bovine milk on ferritin immunoassay has been demonstrated (Orino et al., 2006b), suggesting the presence of ferritin binder in bovine milk component. The cuurent study shows that bovine milk $\alpha$-casein is an FBP that may inhibit milk ferritin immunoassay.

Bovine milk $\alpha$-, $\beta$-, and $\kappa$-caseins were purchased from Sigma (St. Louis, MO). Bovine spleen ferritin monomers were purified from frozen bovine spleen as described previously (Watanabe et al., 1998), and apoferritin was prepared from the bovine spleen ferritin in the reduction step with $100 \mathrm{~m} M$ thioglycolic acid in 100 $\mathrm{m} M$ acetate buffer ( $\mathrm{pH} 5.5$ ) followed by dialysis with PBS (150 m M NaCl, $20 \mathrm{~m} M$ sodium phosphate, $\mathrm{pH} 7.2$ ) to remove the reduction reagent as described previously (Seki et al., 2008). Protein concentration was measured according to the method of Lowry et al. (1951) using BSA (Roche Diagnostics GmbH, Mannheim, Germany) as the standard. Biotinylated rabbit anti-bovine spleen ferritin polyclonal antibody was prepared as described previously (Orino et al., 2006b). Alkaline phosphatase (ALP)-labeled avidin was purchased from Pierce Biotechnology (Rockford, IL).

Ferritin-binding activity was detected as follows. Aliquots $(100 \mu \mathrm{L})$ of casein protein solution $(10 \mu \mathrm{g} /$ $\mathrm{mL}$ ) dissolved in PBS were added to the wells of an Immuno Plate Maxisorp microtiter plate (Nunc, Roskilde, Denmark) and kept overnight at $4^{\circ} \mathrm{C}$ to coat casein protein. After washing with PBS containing 0.5\% Tween 20 (PBST), 300- $\mu$ L aliquots of ELISA buffer (PBS containing $0.1 \%$ Tween 20 and $0.1 \%$ gelatin, $\mathrm{pH}$ 7.2) were added to each well, and the plate was kept for $1 \mathrm{~h}$ at room temperature to mask with gelatin to block nonspecific absorption of ferritin protein. After 
washing with PBST, $100-\mu \mathrm{L}$ aliquots of bovine spleen ferritin or its apoferritin $(2.5 \mu \mathrm{g} / \mathrm{mL})$ in ELISA buffer in the presence or absence of $0.5 M\left(\mathrm{NH}_{4}\right)_{2} \mathrm{SO}_{4}$ were added to each well of the plate, and the plate was incubated at $37^{\circ} \mathrm{C}$ for $2 \mathrm{~h}$. After washing with PBST, $100 \mu \mathrm{L}$ of biotinylated rabbit anti-bovine spleen ferritin polyclonal antibody $(250 \mathrm{ng} / \mathrm{mL})$ diluted with ELISA buffer was added to the wells of the plate, and the plate was incubated at $37^{\circ} \mathrm{C}$ for $1.5 \mathrm{~h}$. After washing with PBST, $100 \mu \mathrm{L}$ of ALP-labeled avidin $(1 \mu \mathrm{g} / \mathrm{mL})$ diluted with ELISA buffer was added to the wells of the plate, and the plate was incubated at $37^{\circ} \mathrm{C}$ for 1.5 h. After washing, the enzyme reaction was carried out as described previously (Orino et al., 1993b). The data obtained are represented as mean \pm SD of 4 replicates. Each test was statistically compared with Student's $t$-test or one-way ANOVA, and a $P$-value $<0.05$ was considered significant for all tests.

Sandwich ELISA for bovine spleen ferritin was performed as described previously (Orino et al., 2006b), except that ALP-labeled avidin was used in place of sheep anti-biotin antibody and ALP-labeled goat anti-sheep IgG antibody. Briefly, $100 \mu \mathrm{L}$ of anti-bovine spleen ferritin antibody $(200 \mathrm{ng} / \mathrm{mL})$ in PBS was added to the wells of an Immuno Plate Maxisorp microtiter plate (Nunc). After washing with PBST, gelatin was masked or used for blocking nonspecific binding of antigen as described above. After masking and washing, $100-\mu \mathrm{L}$ aliquots of bovine spleen ferritin standards in ELISA buffer were added to each well of the plate, and the plate was incubated at $37^{\circ} \mathrm{C}$ for $2 \mathrm{~h}$. After washing with PBST, biotinylated rabbit anti-bovine spleen ferritin polyclonal antibody $(250 \mathrm{ng} / \mathrm{mL})$, diluted with ELISA buffer, was added to the wells of the plate, and the plate was incubated at $37^{\circ} \mathrm{C}$ for $1.5 \mathrm{~h}$. After washing with PBST, $100 \mu \mathrm{L}$ of ALP-labeled avidin $(1 \mu \mathrm{g} /$ $\mathrm{mL}$ ) diluted with ELISA buffer was added to the wells of the plate, and the plate was incubated at $37^{\circ} \mathrm{C}$ for $1.5 \mathrm{~h}$. After washing, the enzyme reaction was carried out as described previously (Orino et al., 2006b). In the recovery test, a known amount of bovine spleen ferritin was added into each casein solution $(2 \mathrm{mg} / \mathrm{mL})$ in ELISA buffer, and the mixture was incubated at room temperature for 30 min. After incubation, the mixture was subjected to sandwich ELISA to determine ferritin concentration.

As shown in Figure 1, ferritin-binding activity was detected in bovine milk $\alpha$-casein, but not in $\beta$ - or $\kappa$-caseins. Gelatin used for blocking nonspecific absorption gave negligible data in the binding of ferritin, biotinylated antibody, and ALP-avidin in the uncoated well. In addition, $\alpha$-casein bound bovine spleen ferritin in a dose-dependent manner $(1-0.25 \mu \mathrm{g} /$ well $)$, but $\beta$ - or $\kappa$-caseins did not bind bovine spleen ferritin (data not

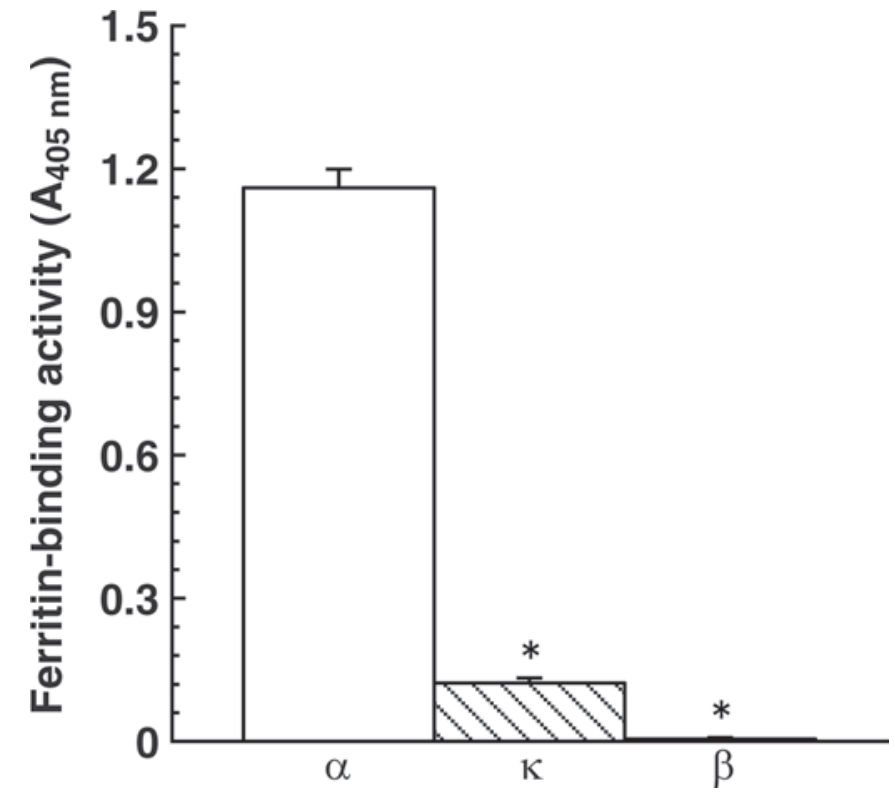

Figure 1. Binding of bovine spleen ferritin to casein family $(\alpha, \beta$, and $\kappa$ ). Bovine spleen ferritin was added to the wells of a casein-coated plate $(1 \mu \mathrm{g} /$ well each $)$ and detected with biotinylated anti-bovine spleen ferritin antibody and alkaline phosphatase-labeled avidin. Each value is the mean $\pm \mathrm{SD}$ of 4 replicates. ${ }^{*} P<0.01$ compared with the binding activity of $\alpha$-casein.

shown). These results indicate that $\alpha$-casein specifically recognizes ferritin. However, $\alpha$-casein did not bind with apoferritin obtained by a reduction step of holoferritin (Figure 2). Although bacterial ferritin is known to bind heme (Kadir and Moore, 1990), mammalian ferritins also seem to bind heme (Précigoux et al., 1994; Orino and Watanabe, 2008; Seki et al., 2008). Apolipoprotein $\mathrm{B}$ is not only an FBP but also a heme-binding protein because ApoB binds biotinylated hemin, and the binding of ApoB with ferritin was inhibited by hemin (Orino and Watanabe, 2008; Seki et al., 2008). This was demonstrated when ApoB did not bind apoferritin following hemin loss on the ferritin surface caused by a reduction step for iron removal from holoferritin (Seki et al., 2008).

Therefore, there is 2-way binding between FBP and ferritin, direct binding with ferritin (Partharathy et al., 2002; Orino et al., 2004; Orino and Watanabe, 2008), and indirect binding with heme on the surface of the ferritin molecule (heme-binding protein; Orino and Watanabe, 2008; Seki et al., 2008). The binding of ApoB with ferritin was strongly inhibited by increasing ionic strength with the addition of $0.5 M\left(\mathrm{NH}_{4}\right)_{2} \mathrm{SO}_{4}$. The binding of $\alpha$-casein to bovine spleen ferritin was also inhibited by increasing ionic strength with the same method (Figure 3). $\alpha$-Casein seems to recognize ferritin through heme-mediated binding. Further study is 


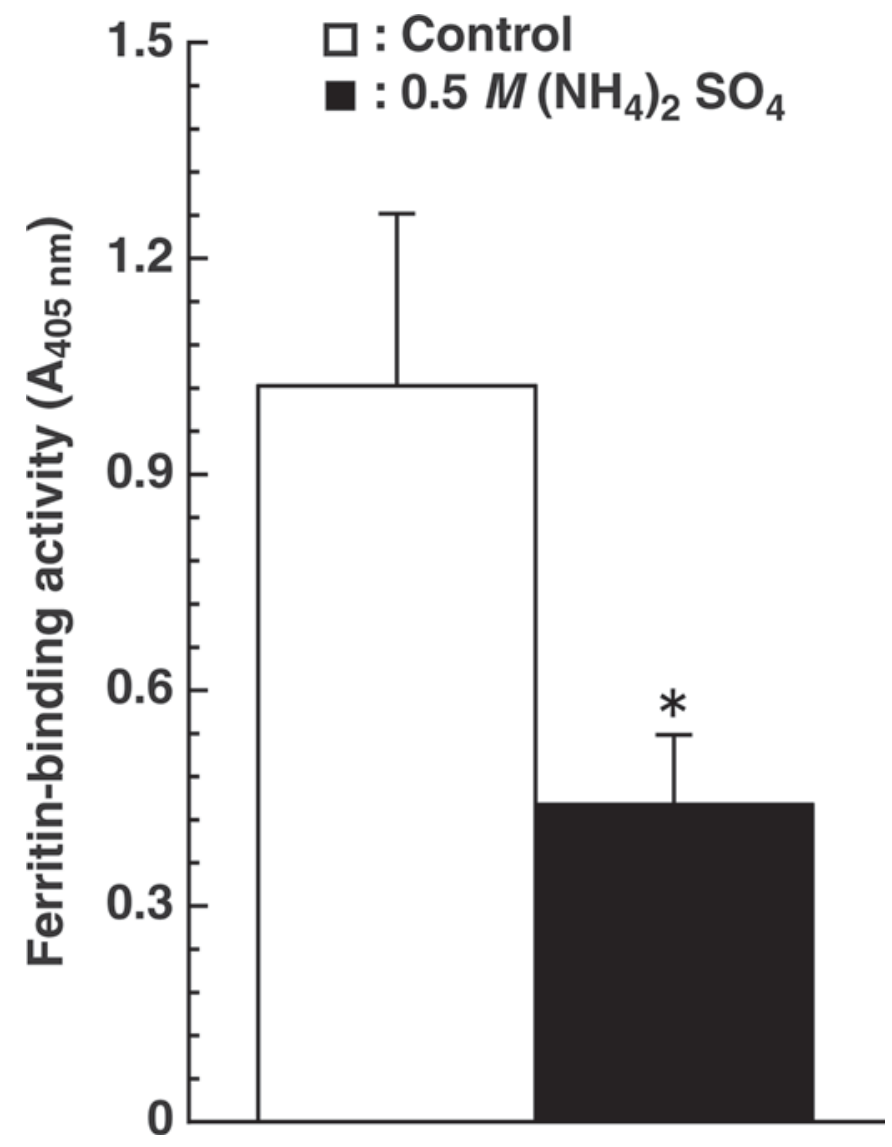

Figure 3. Effect of $0.5 M\left(\mathrm{NH}_{4}\right)_{2} \mathrm{SO}_{4}$ on casein ferritin-binding activity. Binding of bovine spleen ferritin was conducted on an $\alpha$-casein protein-coated plate $(1 \mu \mathrm{g} /$ well $)$ in the presence or absence of $0.5 \mathrm{M}$ $\left(\mathrm{NH}_{4}\right)_{2} \mathrm{SO}_{4}$ and detected with biotinylated anti-bovine spleen ferritin antibody and alkaline phosphatase-labeled avidin. Each value is the mean $\pm \mathrm{SD}$ of 4 replicates. ${ }^{*} P<0.01$ compared with binding activity in the presence of $0.5 \mathrm{M}\left(\mathrm{NH}_{4}\right)_{2} \mathrm{SO}_{4}$.

required to clarify the mechanism involved in $\alpha$-casein and ferritin binding.

Although commercially available $\alpha$-casein contains mainly $\alpha_{\mathrm{S} 1}$-casein in addition to $\alpha_{\mathrm{S} 2}$-casein as resolved by SDS-PAGE (data not shown), we used commercial $\alpha$-casein without separation of $\alpha_{\mathrm{S1}^{-}}$and $\alpha_{\mathrm{S} 2^{-}}$caseins because the amount of $\alpha_{S_{2}}$-casein was negligible. Amino acid sequence homologies among casein families were very low (Stewart et al., 1987; Alexander et al., 1988; Koczan et al., 1991), and those between $\alpha_{\mathrm{S}^{-}}$and $\alpha_{\mathrm{S}^{-}}$ caseins were also low (Stewart et al., 1987; Koczan et al., 1991). On the other hand, the binding of $\alpha_{S 2}$-casein with ferritin may also be caused by the high degree of negatively charged phosphate groups because $\alpha_{\mathrm{S}^{-}}$and

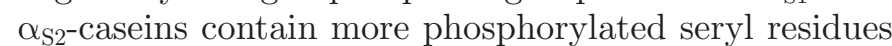
than $\beta$ - and $\kappa$-caseins (Farrell et al., 2004). Although $\kappa$-casein has less phosphate than the other caseins (Farrell et al., 2004), it binds ferritin better than $\beta$-casein (Figure 1). This result suggests the existence of a nega-

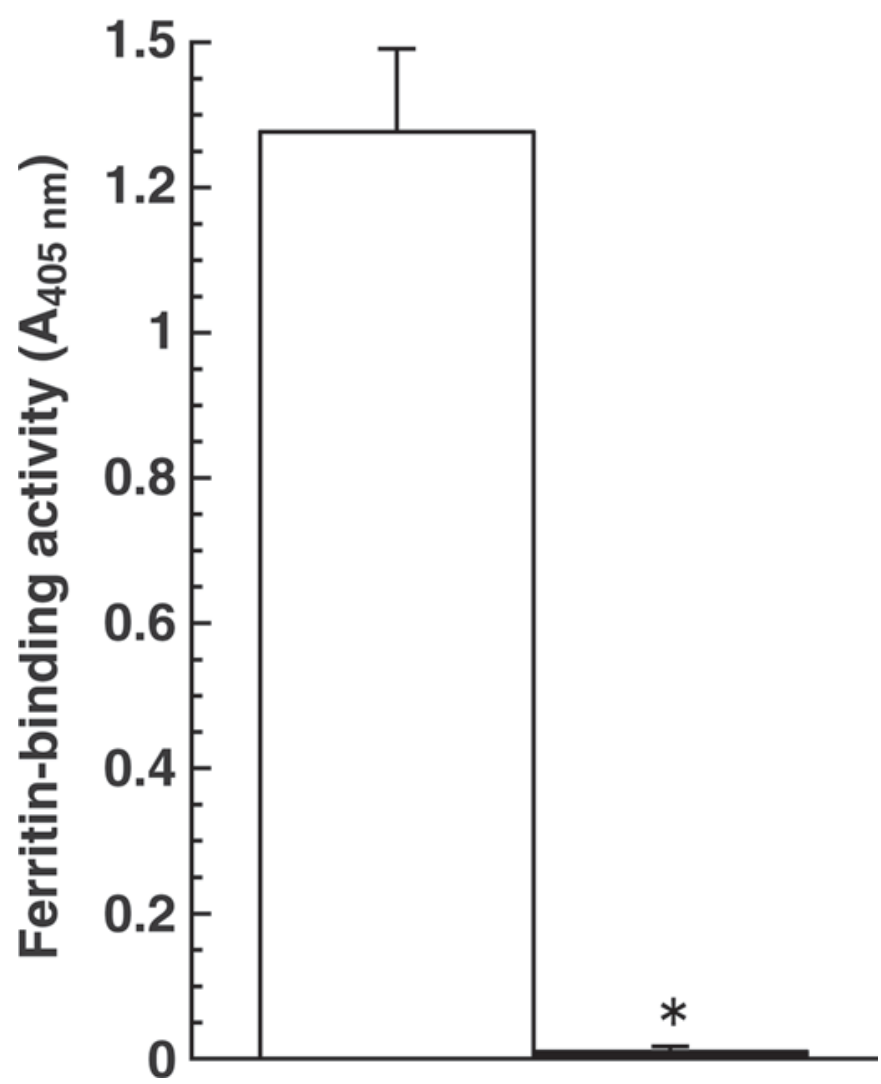

Figure 2. Binding of bovine spleen ferritin and its apoferritin to $\alpha$-casein. Binding of bovine spleen ferritin and its apoferritin was conducted on an $\alpha$-casein protein-coated plate $(1 \mu \mathrm{g} /$ well $)$ and detected with biotinylated anti-bovine spleen ferritin antibody and alkaline phosphatase-labeled avidin. Each value is the mean $\pm \mathrm{SD}$ of 4 replicates. ${ }^{*} P<0.01$ compared with bovine spleen ferritin.

tively charged area on the surface of $\kappa$-casein. Future studies need to identify $\alpha$-casein species and the functional amino acids of $\alpha$-casein.

Tween 20 was used as detergent in the present study to block nonspecific binding. Although the interaction between Tween 20 and $\alpha$-casein protein may affect the binding of ferritin with $\alpha$-casein (Maldonado-Valderrama and Langevin, 2008), Tween 20 did not interfere with the binding of $\alpha$-casein bound to the wells with ferritin (Figure 1). However, it remains to be clarified whether the detergent will have an effect on interactions between $\alpha$-casein and ferritin in solution.

Next, we examined whether $\alpha$-casein inhibits the bovine ferritin immunoassay. Table 1 shows that $\alpha$-casein resulted in a significantly lower recovery $(78-80 \%)$ of added bovine spleen ferritin compared with the $\beta$ - and $\kappa$-casein families (88-92\%), which showed little inhibi- 
Table 1. The effect of bovine casein family on the detection of bovine spleen ferritin ${ }^{1}$

\begin{tabular}{lccc}
\hline Casein subtype & Added ferritin $(\mathrm{ng} / \mathrm{mL})$ & Detected ferritin $(\mathrm{ng} / \mathrm{mL})$ & Detected $(\%)$ \\
\hline$\alpha$-Casein & 2.50 & $2.00 \pm 0.08$ & $80.0 \pm 3.3$ \\
\multirow{3}{*}{-Casein } & 5.00 & $3.90 \pm 0.22$ & $77.5 \pm 4.4$ \\
\multirow{2}{*}{ א-Casein } & 2.50 & $2.40 \pm 0.29$ & $92.0 \pm 5.7^{*}$ \\
& 5.00 & $4.40 \pm 0.28$ & $88.0 \pm 5.7^{*}$ \\
& 2.50 & $2.20 \pm 0.05$ & $89.0 \pm 2.0^{*}$ \\
\hline
\end{tabular}

${ }^{1}$ Known amount of bovine spleen ferritin was added to casein solution (each $2 \mathrm{mg} / \mathrm{mL}$ ), and then the mixture was subjected to sandwich ELISA to measure ferritin. Data represent mean $\pm \mathrm{SD}(\mathrm{n}=4)$.

*Statistically significant $(P<0.05)$ compared with that of $\alpha$-casein with the same amount of ferritin added $(2.5$ or $5 \mathrm{ng} / \mathrm{mL})$.

tory effect. Bovine casein is the major protein $(80 \%)$ in milk $(36 \mathrm{mg} / \mathrm{mL})$, and $\alpha$-casein occupies $50 \%$ of total casein proteins (Jensen, 1995). In measuring bovine milk ferritin, milk is diluted at least 6-fold with the buffer (Orino et al., 2006b), and the final concentration of $\alpha$-casein used in this study was $2 \mathrm{mg} / \mathrm{mL}$. This value is near the physiological concentration that causes the inhibitory effect of bovine milk on ferritin immunoassay. Although ferritin detection was significantly inhibited by $\alpha$-casein, $\beta$ - and $\kappa$-caseins showed minor inhibitory effect on ferritin immunoassay. This suggests that $\beta$ and $\kappa$-caseins have weaker interaction with ferritin or the anti-ferritin antibody used in this immunoassay.

$\alpha$-Casein did not show strong $\alpha$-casein-ferritin interaction in the ferritin immunoassay as in ferritin-binding activity. Although the casein:ferritin weight ratio was 2:1 as calculated from maximum binding (500 ng/well) of $\alpha$-casein in the ferritin binding test, the casein:ferritin weight ratio in the recovery test was 400,000:1. Ferritin is a protein with a large surface area and a molecular mass of $500 \mathrm{kDa}$ (Theil, 1987; Harrison and Arosio, 1996; Orino and Watanabe, 2008) and still may provide binding sites for anti-ferritin antibody on the surface of the molecule as binding with coated casein. However, in the recovery test, $\alpha$-casein may compete for multiple binding sites (epitopes) with polyclonal anti-ferritin antibody. If anti-ferritin antibody has a higher affinity for ferritin than FBP, anti-ferritin antibody may dissociate bound FBP, even after the binding of FBP with ferritin, and bind with ferritin (Orino et al., 2006a). In fact, in a canine ferritin immunoassay, canine serum did not show any inhibitory effect in the ferritin recovery test and ferritin immunoassay although autoantibodies to ferritin were identified as FBP (Watanabe et al., 2000). Polyclonal anti-ferritin antibody used in this study seemed to dissociate some $\alpha$-casein from $\alpha$-casein-ferritin interaction even if the anti-ferritin antibody did not completely inhibit the binding of $\alpha$-casein with ferritin.

This study showed that bovine $\alpha$-casein is a specific FBP that inhibits ferritin immunoassay. Bovine $\alpha$-casein will be the second reported FBP and factor inhibiting ferritin immunoassay, following fibrinogen (Orino et al., 1993b). Moreover, it is likely that bovine milk ferritin binds heme although the binding mechanism of milk FBP has not yet been characterized. Human milk ferritin contains little iron (Arosio et al., 1986). Milk ferritin levels increased in intramammary infection in bovines (Orino et al., 2006b), suggesting that ferritin inhibits bacterial growth by removing iron. After binding of ferritin with iron, milk ferritin may be ejected by milk secretion after binding of $\alpha$-casein with ferritin. Further study needs to clarify the binding mechanism involved in the complex formation between $\alpha$-casein and ferritin as well as its physiological role. The inhibitory effect of bovine milk on ferritin immunoassay was not improved by increasing ionic strength by $0.5 \mathrm{M}\left(\mathrm{NH}_{4}\right)_{2} \mathrm{SO}_{4}$ (Orino et al., 2006b). Bovine milk is likely to contain other FBP besides $\alpha$-casein.

\section{ACKNOWLEDGMENTS}

This study was supported in part by a Grant-in-Aid for Scientific Research (no. S0804) from the School of Veterinary Medicine, Kitasato University, Japan.

\section{REFERENCES}

Addison, G. M., M. R. Beamish, C. N. Hales, H. Hodgkins, A. Jacobs, and P. Llewellin. 1972. An immunoradiometric assay for ferritin in the serum of normal and patients with iron deficiency and iron overload. J. Clin. Pathol. 25:326-329.

Alexander, L. J., A. F. Stewart, A. G. Mackinlay, T. V. Kapelinskaya, T. M. Tkach, and S. I. Gorodetsky. 1988. Isolation and characterization of the bovine $\alpha$-casein gene. Eur. J. Biochem. 178:395-401.

Arosio, P., A. Ponzone, R. Ferrero, I. Renoldi, and S. Levi. 1986. Characteristics of ferritins in human milk secretions: Similarities to serum and tissue isoferritins. Clin. Chim. Acta 161:201-208.

Farrell, H. M. Jr., R. Jimenez-Flores, G. T. Bleck, E. M. Brown, J. E. Butler, L. K. Creamer, C. L. Hicks, K. F. Ng-Kwi-Hang, and H. E. Swaisgood. 2004. Nomenclature of the proteins of cow's milkSixth revision. J. Dairy Sci. 87:1641-1674.

Harrison, P. M., and P. Arosio. 1996. The ferritins: Molecular properties, iron storage function, and cellular regulation. Biochim. Biophys. Acta 1275:161-203. 
Jensen, G. 1995. Protein and amino acid composition of bovine milk Pages 464-472. in Handbook of milk composition. H. E. Swaisgood, ed. Academic Press, New York, NY.

Kadir, F. H. A., and G. R. Moore. 1990. Bacterial ferritin contains 24 haem groups. FEBS Lett. 271:141-143.

Koczan, D., G. Hobom, and H. M. Seyfert. 1991. Genomic organization of the bovine alpha-S1 casein gene. Nucleic Acids Res. 19:55915596 .

Lorier, M. A., J. L. Herron, and R. W. Carrel. 1985. Detecting iron deficiency by serum tests. Clin. Chem. 31:337-338.

Lowry, O. H., N. J. Rosebrough, A. L. Farr, and R. J. Randall. 1951. Protein measurement with the Folin phenol reagent. J. Biol. Chem. 193:265-275

Maldonado-Valderrama, J., and D. Langevin. 2008. On the difference between foams stabilized by surfactants and whole casein or $\beta$-casein. Comparison of foams, foam films, and liquid surfaces studies. J. Phys. Chem. 112:3989-3996.

Massover, W. H. 1994. $\alpha_{2}$-Macroglobulin: A ferritin-binding protein. Ann. N. Y. Acad. Sci. 737:468-471.

Orino, K., T. Ishiji, S. Yamamoto, and K. Watanabe. 2004. Characterization of bovine serum ferritin-binding proteins. Comp. Biochem. Physiol. 137A:375-381.

Orino, K., M. Saji, Y. Ozaki, T. Ohya, S. Yamamoto, and K. Watanabe. 1993a. Inhibitory effects of horse serum on immunoassay of horse ferritin. J. Vet. Med. Sci. 55:45-49.

Orino, K., M. Uehara, S. Okano, and K. Watanabe. 2006a. Purification and characterization of canine serum ferritin-binding proteins. Biometals 19:315-322.

Orino, K., and K. Watanabe. 2008. Molecular, physiological and clinical aspects of the iron storage protein ferritin. Vet. J. 178:191-201.

Orino, K., S. Watanabe, H. Ohtsuka, M. Kohiruimaki, and K. Watanabe. 2006b. Measurement of ferritin in bovine milk and its clinical significance. J. Dairy Sci. 89:3842-3845.

Orino, K., S. Yamamoto, and K. Watanabe. 1993b. Fibrinogen as a ferritin-binding protein in horse plasma. J. Vet. Med. Sci. 55:785787.

Ota, T., and I. Katsuki. 1998. Ferritin subunits in sera and synovial fluids from patients with rheumatoid arthritis. J. Rheumatol. $25: 2315-2318$.
Parthasarathy, N., S. V. Torti, and F. M. Torti. 2002. Ferritin binds to light chain of human H-kininogen and inhibits kallikrein-mediated bradykinin release. Biochem. J. 365:279-286.

Précigoux, G., J. Yariv, B. Gallois, A. Dautant, C. Courseille, and B. L. d'Estaintot. 1994. A crystallographic study of haem binding to ferritin. Acta Crystallogr. D Biol. Crystallogr. 50:739-743.

Rashid, K. A., S. Hevi, Y. Chens, F. L. Cahérec, and S. L. Chuck. 2002. A proteomic approach identifies proteins in hepatocytes that bind nascent apolipoprotein B. J. Biol. Chem. 24:22010-22017.

Santambrogio, P., and W. H. Massover. 1989. Rabbit serum alpha2-macroglobulin binds to liver ferritin: Association causes a heterogeneity of ferritin molecules. Br. J. Haematol. 71:281-290.

Seki, T., T. Kunichika, K. Watanabe, and K. Orino. 2008. Apolipoprotein $\mathrm{B}$ binds ferritin by heme-mediated binding: Evidence of direct binding of apolipoprotein $\mathrm{B}$ and ferritin to hemin. Biometals 21:61-69.

Stewart, A. F., J. Bonsing, C. W. Beattie, F. Shah, I. M. Willis, and A. G. Mackinlay. 1987. Complete nucleotide sequences of bovine as2- and $\beta$-casein cDNAs: Comparisons with related sequences in other species. Mol. Biol. Evol. 4:231-241.

Theil, E. C. 1987. Ferritin: Structure, gene regulation, and cellular function in animals, plants, and microorganisms. Annu. Rev. Biochem. 56:289-315.

Torti, S. V., and F. M. Torti. 1998. Human H-kininogen is a ferritinbinding protein. J. Biol. Chem. 273:13630-13635.

Walters, G. O., F. M. Miller, and M. Worwood. 1973. Serum ferritin concentration and iron stores in normal subjects. J. Clin. Pathol. $26: 770-772$.

Watanabe, K., K. Hayashi, T. Miyamoto, M. Tanaka, S. Okano, and S. Yamamoto. 2000. Characterization of ferritin and ferritin-binding protein in canine serum. Biometals 13:57-63.

Watanabe, K., M. Ozawa, H. Ochiai, H. Kamohara, N. Iijima, H. Negita, K. Orino, and S. Yamamoto. 1998. Change in iron and ferritin in anemic calves infected with Theileria sergenti. J. Vet. Med. Sci. 60:943-947. 